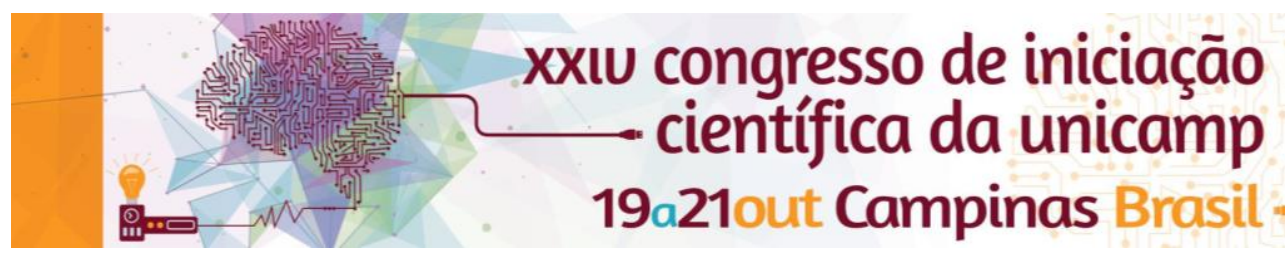

\title{
Cimento Alternativo à base de Magnésio
}

\section{Beatriz M. T. Gonçalves}

\section{Resumo}

O presente projeto de iniciação científica teve por objetivo estudar as principais propriedades mecânicas dos ligantes à base de magnésio, assim como o desenvolvimento de matrizes cimentícias alternativas para uso na construção civil. Dessa forma, trabalhou-se com um aglomerante alternativo à base de óxido de magnésio, denominado Cimento Sorel, sendo o desempenho destes materiais analisado por meio das normas (adaptadas) NBR 7222 - Concreto e argamassa - Determinação da resistência à tração por compressão diametral de corpos de prova cilíndricos; NBR 7215 - Cimento Portland - Determinação da Resistência à compressão e; NBR13279 - Argamassa para assentamento e revestimento de paredes e tetos, permitindo compreender também as questões de desempenho, responsabilidade sócio-ambiental e requisitos mínimos de sustentabilidade aplicada na construção civil, uma vez que a presente técnica está associada à produção de aglomerantes com menor emissão de $\mathrm{CO} 2$ para atmosfera.

\section{Palavras-chave:}

Construção Civil, Aglomerante Alternativo, Cimento Magnesiano

\section{Introdução}

Como observado na literatura, vários cimentos (aglomerantes) à base de magnésio foram objetos de estudos no passado. Hoje, o óxido de magnésio utilizado é produzido por calcinação em altas temperaturas e é referido na indústria como sendo "queimado até a morte" e não é tão reativo como a magnésia feita a temperaturas mais baixas.

Os referidos estudos foram propostos com o intuito de demonstrar ser possível o uso de novos aglomerantes alternativos ao cimento Portland na construção civil, de forma a contribuir à indústria de artefatos e/ou elementos construtivos para produção de placas, painéis de vedação, telhas e também outros elementos construtivos.

\section{Resultados e Discussão}

Na primeira etapa do projeto foi previsto a moldagem de corpos de prova com diferentes concentrações de Óxido de Magnésio (20\% e 40\%), e dos Carbonatos de Cálcio e de Magnésio. Estes foram submetidos a ensaios mecânicos de tração e compressão 7 (sete) dias após sua confecção, conforme procedimento descrito nas normas (adaptadas) NBR 7222, NBR e NBR13279, para realização de estudo comparativo entre as proporções de aglomerantes e aditivos.

A segunda etapa consistiu na determinação da massa específica dos materiais utilizados para a confecção dos corpos de prova com o auxílio do tubo de Chapman, e na análise de durabilidade dos moldes que apresentaram melhor resistência na etapa inicial do projeto, no caso os com maiores concentrações de Óxido de Magnésio.

Algumas amostras foram imersas em ácido e outras em água para posterior comparação com os corpos que foram deixados ao ar livre.

\section{Conclusões}

Notou-se que no geral para uma mesma quantidade de Óxido de Magnésio e das cargas Carbonatos de Cálcio e de Magnésio, os corpos de provas confeccionados com concentrações mais altas do sal (40\%) obtiveram melhor desempenho quando submetidos à esforços de tração $e$ compressão se comparados com concentrações de $20 \%$ do sal.

É importante que se estude o teor ótimo das concentrações de sulfato de magnésio e das cargas minerais (carbonatos) nos compósitos produzidos, uma vez que o desenvolvimento de novas formulações alternativas poderá otimizar o uso de $\mathrm{MgO}_{2}$, além de promover uma redução de custos na construção civil com maior responsabilidade sócio-ambiental.

\footnotetext{
${ }^{1}$ A. K. Misra, R.Mathur. Magnesium oxychloride cement concrete. Bull. Mater Sci. v.30 n.3 (2007). 239-246.

2 GOMES, C.E.M; CAMARINI, G. NOCMAT 2013 - Magnesium Oxysulfate Fibercement, 14th International Conference on Non Conventional Construction Materials and Technologies - João Pessoa/BRAZIL, 2013. Key Engineering $\begin{array}{lllll}\text { Materials } & \text { Vol. } & 600 & \text { (2014) pp } & \text { 308-318 }\end{array}$ DOI:10.4028/www.scientific.net/KEM.600.308
} 